\title{
Advanced Perkinsus Marinus Infections In Crassostrea Ariakensis Maintained Under Laboratory Conditions
}

\author{
JA Moss \\ Virginia Institute of Marine Science \\ EM Burreson \\ Virginia Institute of Marine Science \\ Kimberly S. Reece \\ Virginia Institute of Marine Science
}

Follow this and additional works at: https://scholarworks.wm.edu/vimsarticles

Part of the Marine Biology Commons

\begin{abstract}
Recommended Citation
Moss, JA; Burreson, EM; and Reece, Kimberly S., Advanced Perkinsus Marinus Infections In Crassostrea Ariakensis Maintained Under Laboratory Conditions (2006). Journal Of Shellfish Research, 25(1), 65-72. 10.2983/0730-8000(2006)25[65:APMIIC]2.0.C0;2
\end{abstract}

This Article is brought to you for free and open access by the Virginia Institute of Marine Science at W\&M ScholarWorks. It has been accepted for inclusion in VIMS Articles by an authorized administrator of W\&M ScholarWorks. For more information, please contact scholarworks@wm.edu. 


\title{
ADVANCED PERKINSUS MARINUS INFECTIONS IN CRASSOSTREA ARIAKENSIS MAINTAINED UNDER LABORATORY CONDITIONS
}

\author{
JESSICA A. MOSS, EUGENE M. BURRESON AND KIMBERLY S. REECE* \\ Virginia Institute of Marine Science, The College of William and Mary, Gloucester Point, VA 23062
}

\begin{abstract}
The Suminoe oyster, Crassostrea ariakensis, has been under investigation since the early 1990s for potential use in restoring the commercial harvest or for aquaculture of oysters in the Chesapeake Bay, USA. Initial studies focusing on C. ariakensis documented a significant level of tolerance to the protozoan parasite Perkinsus marinus, a pathogen found in almost all reaches of the Bay and widely acknowledged as one of the main reasons for the decline in the eastern oyster, Crassostrea virginica, harvest since the late 1980s. Crassostrea ariakensis was demonstrated to acquire P. marinus, however infection intensities, as measured using Ray's thioglycollate medium assay indices, generally were found to be light. As part of a series of experiments to study potential impacts on the Chesapeake Bay region of pathogens found in C. ariakensis in Asia, a challenge experiment was conducted to study the pathogenicity of Perkinsus olseni to C. ariakensis. During this study, we observed the acquisition of moderate and heavy infection intensities of $P$. marinus in triploid $C$. ariakensis oysters being maintained in the laboratory. Results suggest that there may be some risk of mortality from $P$. marinus if $C$. ariakensis is held under stressful conditions at least in hatchery or laboratory settings.
\end{abstract}

KEY WORDS: Perkinsus marinus, Crassostrea ariakensis, PCR, RFTM, oyster

\section{INTRODUCTION}

The eastern oyster, Crassostrea virginica (Gmelin, 1791), an integral part of the economy and ecology of the Chesapeake Bay, has been in a severe state of decline in recent decades. Two pathogens, Haplosporidium nelsoni (Haskin, Stauber \& Mackin, 1966) and Perkinsus marinus (Mackin, Owen \& Collier, 1950), the parasites responsible for the diseases known as MSX and dermo respectively, have contributed significantly to the decimation of the oyster populations in Chesapeake Bay since the 1950s (Sindermann 1990).

The decline in oyster production in Virginia led to the formation of a number of panels in the early 1990s to make recommendations on restoring oyster populations. One option currently being seriously considered is the introduction and use of a nonnative oyster in Chesapeake Bay. A Virginia Institute of Marine Science (VIMS) study conducted in 1996 focusing on the Pacific oyster, Crassostrea gigas (Thunberg, 1793), documented lower disease susceptibility in $C$. gigas than in the native eastern oyster, $C$. virginica; however, growth rates of the Pacific oyster were equal to or inferior to the native oyster in the Chesapeake Bay (Calvo et al. 1999). A 1998 field-based study on another Asian oyster, the Suminoe oyster, Crassostrea ariakensis (Fujita, 1913), documented rapid growth and survival in that species, as compared with C. virginica, even when endemic diseases were prevalent (Calvo et al. 2001). Although initial baseline samples of $C$. ariakensis in that study revealed a $12 \%$ prevalence of $P$. marinus, all subsequent samples collected after field deployment showed $C$. virginica with higher $P$. marinus prevalence than $C$. ariakensis. Additionally, Ray fluid thioglycollate medium (RFTM) (Ray 1952) diagnoses showed several heavy $P$. marinus infections in $C$. virginica, however, only light infections were observed in C. ariakensis (Calvo et al. 2001).

In this report we describe the first account of moderate to heavy $P$. marinus infections in $C$. ariakensis. The oysters in this study were held in laboratory aquaria at VIMS during a challenge experiment conducted to examine the potential pathogenicity of $\mathrm{Per}$ kinsus olseni Lester and Davis, 1981, to C. ariakensis, because $P$.

\footnotetext{
*Corresponding author. E-mail: kreece@vims.edu
}

olseni was found during a recent survey of $C$. ariakensis populations in Asia (Moss \& Reece 2005). Prior to the start of the challenge experiment, $C$. ariakensis were initially determined to be Perkinsus sp.-free, based on molecular diagnostics using PCR (Casas et al. 2002). The oysters acquired detectable levels of the parasite, however, after being held for about 8 weeks in the laboratory aquaria. We used the infected oysters in our challenge study, despite baseline $P$. marinus infection prevalence, to examine the potential for $C$. ariakensis oysters to become coinfected with multiple Perkinsus species. We report here our observations regarding the $P$. marinus infection levels observed in $C$. ariakensis during this challenge experiment.

\section{MATERIALS AND METHODS}

\section{Experimental Design}

On January 24, 2005, 120 market sized ( $75 \mathrm{~mm}$ shell height) triploid $C$. ariakensis were received from the Aquaculture Genetics and Breeding Technology Center hatchery at VIMS. The animals were held for 4 days inside a plastic mesh bag in a holding tank prior to bringing them into the laboratory aquaria. The holding tank was not covered and there was flow-through of nonfiltered York River water of approximately $9^{\circ} \mathrm{C}$ and 16 ppt salinity. On removal from the holding tank, 20 C. ariakensis were immediately sacrificed, and gill and mantle tissues were excised aseptically from each animal for DNA extraction. Genomic DNA of each oyster was used in a PCR-based molecular diagnostic assay (Casas et al. 2002) to examine the animals for the presence of DNA from Perkinsus spp. parasites. The animals were subsequently held for 59 days in 10-gallon glass aquaria that were maintained at $20^{\circ} \mathrm{C}$ and 25 ppt salinity at a density of approximately 25 oysters per tank and were fed $0.1 \mathrm{~g}$ oyster $^{-1}$ algal food daily (Reed Mariculture, San Jose, CA). At the end of 59 days, on March 24, 2005, five C. ariakensis were sacrificed and gill and mantle were excised aseptically from each animal to be used in Perkinsus spp. screening by PCR assays as described later.

On March 28, 2005, the remaining C. ariakensis $(n=60)$ were used in a challenge experiment designed to evaluate the pathogenicity of $P$. olseni to $C$. ariakensis. Twenty $C$. ariakensis received single pallial cavity injections of $100 \mu \mathrm{L}$ of 25 ppt sterile artificial 
seawater (SASW) through a notch in the shell, and 40 animals were inoculated with $10^{5} \log$ phase cultured $P$. olseni cells per gram body weight in a $100-\mu \mathrm{L}$ volume. The clonal $P$. olseni culture isolated from a Japanese Venerupis philippinarum (Adams and Reeve, 1850) clam was obtained from Mr. Chris Dungan, Maryland DNR Cooperative Oxford Laboratory, Oxford Maryland, (ATCC PRA-181). Thirty additional untreated, control $C$. ariakensis were neither notched nor inoculated, but held in separate aquaria and otherwise maintained and fed in the same manner as the experimental animals for the duration of the experiment. Those $C$. ariakensis inoculated with 25 ppt SASW were maintained in one 10-gallon aquarium, and those inoculated with $P$. olseni were split evenly between two aquaria. All aquaria were identical and each tank was covered with a plexiglass lid.

All aquaria environments were maintained at $20^{\circ} \mathrm{C}$ to $22^{\circ} \mathrm{C}$ and contained $25 \mathrm{ppt}$ aerated, $1-\mu \mathrm{m}$ filtered York River water, two thirds of which was removed each week and replaced with an equal volume of clean, $25 \mathrm{ppt}, 1-\mu \mathrm{m}$ filtered York River water. Animals were fed daily a single dose of approximately $0.1 \mathrm{~g}$ oyster $^{-1}$ algal feed (Reed Mariculture).

Aquaria were checked daily for oyster mortalities, and moribund animals were removed. The cumulative mortality was calculated for each sample as the sum of the mortalities that occurred during the course of the experiment, which started 59 days after the C. ariakensis were brought into the aquaria, divided by the number of live animals at the start of the experiment. When moribund animals were discovered, if adequate undegraded tissues remained they were processed for analysis. Gill and mantle tissues were removed with a portion preserved in $95 \%$ ethanol for DNA extraction and molecular diagnostics and gill, mantle and rectal tissues were processed for Ray fluid thioglycollate medium (RFTM) assay (Ray 1952). After $27^{\circ} \mathrm{C}$ incubation for 5-6 days in RFTM, tissues were removed from the culture tubes, macerated on microscope slides and stained with Lugol iodine. Stained, cover-slipped tissue preparations were examined under a light microscope and Perkinsus sp. tissue burdens were enumerated on a scale from rare (R) to very heavy ( $\mathrm{VH}$ ) based on the categories of Ray (1952, 1954). Visceral mass tissue sections were preserved in Davidson's solution for histological analysis (Shaw \& Battle 1957).

\section{Experimental Sampling}

Because of space constraints in the laboratory, the untreated $C$. ariakensis that were remaining after 37 days were sacrificed and tissues were taken for DNA, RFTM and histological analysis of disease status as described earlier. For those tanks in which $C$. ariakensis were inoculated with either 25 ppt SASW (one tank) or with $P$. olseni (two tanks), two randomly chosen oysters from each tank were removed and sacrificed for disease diagnosis on days 21, 44 and 59 postinoculation. The challenge experiment was terminated on day 72 and all remaining animals were sacrificed and tissues preserved as mentioned earlier for DNA, RFTM and histological analysis.

\section{Nucleic Acid Extraction}

Genomic DNA was extracted from the excised mantle and gill tissue snips, using a DNeasy Tissue Kit (Qiagen Inc., Valencia, CA), following manufacturer's protocols, except that DNA was eluted in a single $200-\mu \mathrm{L}$ volume of elution buffer after a $10 \mathrm{~min}$ incubation at room temperature (approximately $20^{\circ} \mathrm{C}$ ).

\section{SSU Genes}

To assure that PCR amplifiable DNA was present in all extracted samples, genomic DNAs were tested using universal small subunit (SSU) ribosomal RNA gene primers 16S-A (5' CCG AAT TCG TCG ACA ACC TGG TTG ATC CTG CCA GT 3') and 16S-B (5' GGA TCC AAG CTT GAT CCT TCT GCA GGT TCA CCT AC $3^{\prime}$ ) (modified from Medlin et al. 1988) with an expected amplification product of approximately $1,800 \mathrm{bp}$. Each $25-\mu \mathrm{L}$ reaction contained $20 \mathrm{mM}$ Tris- $\mathrm{HCl}$ (pH8.4), $50 \mathrm{mM} \mathrm{KCl}, 0.75 \mathrm{mM}$ $\mathrm{MgCl}_{2}, 0.1 \mathrm{mM}$ of each dNTP, $0.5 \mu \mathrm{M}$ each primer, $0.0125 \mathrm{U}$

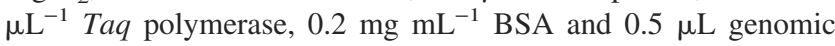
DNA ( 10-50 ng total). Amplifications were performed with an initial denaturation of $94^{\circ} \mathrm{C}$ for $4 \mathrm{~min}$, followed by 35 cycles at $94^{\circ} \mathrm{C}$ for $30 \mathrm{sec}, 45^{\circ} \mathrm{C}$ for $30 \mathrm{sec}, 65^{\circ} \mathrm{C}$ for $2 \mathrm{~min}$, with a final elongation of $65^{\circ} \mathrm{C}$ for $2 \mathrm{~min}$. After amplification, $3 \mu \mathrm{L}$ of PCR product were analyzed by agarose gel electrophoresis $(2 \%)$, stained with ethidium bromide and visualized under UV light. Images were recorded with an Alpha Innotech FlourChem (SanLeandro, CA) imaging system.

\section{Genus-specific Perkinsus sp. PCR Assay}

Screening for Perkinsus sp. DNA was performed using Perkinsus genus-specific primers, PerkITS-85 (5' CCG CTT TGT TTG GAT CCC $3^{\prime}$ ) and PerkITS-750 (5' ACA TCA GGC CTC TAA TGA TG $3^{\prime}$ ) (Casas et al. 2002) that target the internal transcribed spacer (ITS) region of the ribosomal RNA gene complex. Each PCR reaction contained the following: PCR buffer at a concentration of $20 \mathrm{mM}$ Tris- $\mathrm{HCl}$ (pH8.4), $50 \mathrm{mM} \mathrm{KCl}, 1.5 \mathrm{mM} \mathrm{MgCl}_{2}, 0.2$

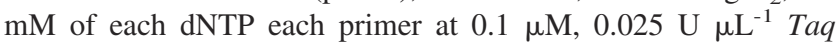
polymerase, $0.05 \mathrm{mg} \mathrm{mL}^{-1} \mathrm{BSA}$ and $0.5 \mu \mathrm{L}$ genomic DNA $(\sim 10$ $50 \mathrm{ng}$ total). Amplifications were performed with an initial denaturation of $95^{\circ} \mathrm{C}$ for 4 min followed by 40 cycles of $95^{\circ} \mathrm{C}$ for 1 $\min , 53^{\circ} \mathrm{C}$ for $1 \mathrm{~min}, 65^{\circ} \mathrm{C}$ for $3 \mathrm{~min}$, with a final elongation of $65^{\circ} \mathrm{C}$ for $5 \mathrm{~min}$. After amplification, $4 \mu \mathrm{L}$ of PCR product were analyzed as described earlier.

\section{Perkinsus Species-specific Assays}

Identification of the Perkinsus species that was infecting animals shown to have positive amplification products with the Perkinsus genus-specific assay was accomplished through the use of $P$. marinus and P. olseni species-specific PCR assays. Perkinsus marinus-specific primers PmarITS-70F (5' CCT TTG YTW GAG WGT TGC CAG ATG 3') and PmarITS-600R (5' CGA GTT TGC GAG TAC CTC KAG AG $3^{\prime}$ ) (Audemard et al. 2004) and $P$. olseni-specific primers designed for this study Pols-140F (5' GAC CGC CTT AAC GGG CCG TGT T 3') and PolsITS-600R (5' GGR CTT GCG AGC ATC CAA AG 3') were used in separate $25-\mu \mathrm{L}$ reactions. PCR reactions for the $P$. marinus ITS region contained the following: PCR buffer at a concentration of $20 \mathrm{mM}$ Tris- $\mathrm{HCl}$ (pH8.4), $50 \mathrm{mM} \mathrm{KCl}, 1.5 \mathrm{mM} \mathrm{MgCl}_{2}, 0.2 \mathrm{mM}$ each

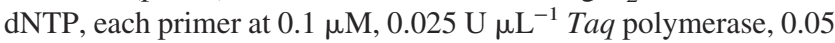
$\mathrm{mg} \mathrm{mL} \mathrm{m}^{-1} \mathrm{BSA}$ and $0.5 \mu \mathrm{L}$ genomic DNA ( 10-50 ng). Amplifications were performed with an initial denaturation of $95^{\circ} \mathrm{C}$ for 4 min followed by 40 cycles of $94^{\circ} \mathrm{C}$ for $1 \mathrm{~min}, 57^{\circ} \mathrm{C}$ for $1 \mathrm{~min}, 65^{\circ} \mathrm{C}$ for $3 \mathrm{~min}$, with a final elongation of $65^{\circ} \mathrm{C}$ for $10 \mathrm{~min}$. PCR reactions for the $P$. olseni ITS region contained the following: PCR buffer at a concentration of $20 \mathrm{mM}$ Tris- $\mathrm{HCl}$ (pH8.4), $50 \mathrm{mM} \mathrm{KCl}$, $1.5 \mathrm{mM} \mathrm{MgCl} 2,0.2 \mathrm{mM}$ each dNTP, each primer at $0.1 \mu \mathrm{M}, 0.025$ $\mathrm{U}_{\mu \mathrm{L}^{-1}} \mathrm{Taq}$ polymerase, $0.05 \mathrm{mg} \mathrm{mL}^{-1} \mathrm{BSA}$ and $0.5 \mu \mathrm{L}$ genomic DNA ( 10-50 ng). Thermocycling parameters were as follows: an 
initial denaturation of $95^{\circ} \mathrm{C}$ for 4 min followed by 40 cycles of: $94^{\circ} \mathrm{C}$ for $1 \mathrm{~min}, 62^{\circ} \mathrm{C}$ for $1 \mathrm{~min}, 65^{\circ} \mathrm{C}$ for $3 \mathrm{~min}$, all followed by a final elongation step of $65^{\circ} \mathrm{C}$ for $10 \mathrm{~min}$. After amplification, for each species-specific reaction, $4 \mu \mathrm{L}$ of PCR product were analyzed as described earlier.

Specificity of $P$. olseni primers was tested against $P$. marinus and Perkinsus chesapeaki McLaughlin, Tall, Shaheen, Elsayed and Faisal 2000, DNAs. In addition, amplification products from positive $P$. olseni-specific reactions were sequenced. PCR products were cloned into the plasmid pCR4-TOPO and transformed into $E$. coli using a TOPO TA Cloning Kit (Invitrogen, Carlsbad, CA) following the manufacturer's protocols. Transformed bacterial colonies were picked from agar plates using a sterile wooden toothpick and were inoculated into $10 \mu \mathrm{L}$ of sterile water in 200 $\mu \mathrm{L}$ plastic strip tubes. Inoculated water samples were boiled for 4 min at $94^{\circ} \mathrm{C}$ and $0.5 \mu \mathrm{L}$ of the boiled preparation was used in an M13 PCR reaction using the forward and reverse primers supplied in the cloning kit. Each $25 \mu \mathrm{L}$ reaction contained the following: 20 $\mathrm{mM}$ Tris- $\mathrm{HCl}(\mathrm{pH} 8.4), 50 \mathrm{mM} \mathrm{KCl}, 1.5 \mathrm{mM} \mathrm{MgCl}_{2}, 0.2 \mathrm{mM}$

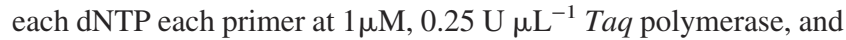
$0.2 \mathrm{mg} \mathrm{mL}^{-1}$ BSA. Thermocycling parameters were as follows: an initial denaturation at $94^{\circ} \mathrm{C}$ for 2 min, followed by 30 cycles of $94^{\circ} \mathrm{C}$ for $30 \mathrm{sec}, 54^{\circ} \mathrm{C}$ for $30 \mathrm{sec}$ and $72^{\circ} \mathrm{C}$ for $1 \mathrm{~min}$, followed by a final elongation at $72^{\circ} \mathrm{C}$ for $5 \mathrm{~min}$. Following amplification using the M13 primer pairs, $3 \mu \mathrm{L}$ of each PCR product were analyzed as mentioned earlier. Prior to sequencing, PCR products from clones containing the correct insert size were treated with shrimp alkaline phosphatase (SAP) and exonuclease I (Exo I) (Amersham Biosciences, Piscataway, NJ), to degrade nucleotides and singlestranded DNA (primers) remaining after PCR. Five micro liters of the M13 PCR product were combined with 0.5 units of SAP and 5.0 units of Exo I, and incubated at $37^{\circ} \mathrm{C}$ for $30 \mathrm{~min}, 80^{\circ} \mathrm{C}$ for 15 min, and $15^{\circ} \mathrm{C}$ for at least $5 \mathrm{~s}$. Clean PCR products from plasmid inserts were sequenced bidirectionally using the Big Dye Terminator kit (Applied Biosystems, Norwalk, CT) with M13 sequencing primers, and using $5-\mu \mathrm{L}$ reactions with 0.125 times the concentration of Big Dye reagent specified in the manufacturer's protocols. Each $5 \mu \mathrm{L}$ reaction contained $0.0625 \mu \mathrm{L}$ of Big Dye, $0.96875 \mu \mathrm{L}$ of $5 \times$ buffer, $1.6 \mathrm{pmol}$ of each primer, and $10 \mathrm{ng}$ of clean PCR product. Thermocycling parameters were as follow: 25 cycles of $96^{\circ} \mathrm{C}$ for $1 \mathrm{~min}, 96^{\circ} \mathrm{C}$ for $10 \mathrm{sec}, 50^{\circ} \mathrm{C}$ for $5 \mathrm{sec}, 60^{\circ} \mathrm{C}$ for $4 \mathrm{~min}$, followed by a final incubation at $4^{\circ} \mathrm{C}$ until the sequencing reaction products were precipitated using the ethanol/sodium acetate precipitation method (ABI User Bulletin, April 11, 2002). Precipitated sequencing reaction products were resuspended in $20 \mu \mathrm{L}$ of $\mathrm{Hi}-\mathrm{Di}$ formamide (Applied Biosystems) and $10 \mu \mathrm{L}$ of each were electrophoretically separated on an ABI 3100 Prism Genetic Analyzer.

\section{RFLP}

For further confirmation of the presence of $P$. marinus or $P$. olseni DNA, and to further verify the specificity of the Perkinsus species-specific primer sets, genus-specific PerkITS-85/750 amplification products were digested with $M b o$ I restriction endonuclease (New England Biolabs, Beverly, MA). Based on analyzing published and unpublished sequence data of all known Perkinsus species, this enzyme will cut the approximately 760 bp ITS fragment of $P$. marinus DNA that is generated in the genus-specific assay to yield a 3-fragment digestion profile unique to this species. The fragments should be approximately 17,226 and 264 bp in length. For P. olseni, Mbo I should cut the ITS region fragment to yield a 4-fragment digestion profile with fragment lengths of approximately $64,85,251$ and 262 bp in length. Each $10-\mu \mathrm{L}-$ digestion reaction contained $5 \mu \mathrm{L}$ of PCR product, $8.2 \mu \mathrm{L}$ of sterile distilled water, $1.5 \mu \mathrm{L}$ of $10 \mathrm{X}$ NEB buffer 3 , and $0.3 \mu \mathrm{L}$ of restriction enzyme. As controls, separate oyster genomic DNA samples, determined previously to be infected with $P$. olseni and $P$. marinus, and plasmid-purified $P$. chesapeaki ITS DNA was first amplified with the Perkinsus genus-specific primers, Perk-ITS85/ 750 , as described above and then digested with $M b o$ I restriction endonuclease. We chose to use only $P$. marinus, $P$. olseni and $P$. chesapeaki DNAs as controls, because these were the Perkinsus species, that we expected might be present in our samples. Perkinsus olseni was being used in the experiment and $P$. marinus and $P$. chesapeaki are common to Chesapeake Bay and potentially their DNAs could have contaminated the $1-\mu \mathrm{m}$ filtered York River water, although this was not likely. PCR products were digested at $37^{\circ} \mathrm{C}$ for $6 \mathrm{~h}$ and $10 \mu \mathrm{L}$ of the digested PCR product was electrophoresed on a $3 \%$ agarose gel that was $1.5 \%$ agarose and $1.5 \%$ low melt agarose (Fisher Scientific, Raleigh, NC), stained with ethidium bromide and visualized under UV light. Images were recorded with an Alpha Innotech FlourChem (SanLeandro, CA) imaging system.

\section{Histological Analysis}

Tissues preserved for histological analysis in Davidson's solution (Shaw \& Battle 1957) were dehydrated in a series of ethanol baths, infiltrated with paraffin and embedded in paraffin blocks prior to sectioning. Sections of 5 - $\mu \mathrm{m}$ thickness were stained with Harris-hematoxylin and eosin. Histological sections of infected oysters were examined using light microscopy to visualize Perkinsus sp. parasite cells in situ.

\section{In-situ Hybridization}

Representative tissue sections from a few of the $C$. ariakensis oysters determined to have $P$. marinus or mixed infections of both $P$. marinus and $P$. olseni by species-specific PCR were evaluated by in situ hybridization (ISH). A genus-specific 5' end digoxigeninlabeled Perkinsus probe (Elston et al. 2004) was used to specifically target SSU rRNA sequences. Perkinsus species-specific probes, PmarLSU-181DIG (5'-GACAACGGCGAACGACTC-3'), specific to $P$. marinus, and PolsLSU-464DIG (5'-CTCACAAGTGCCAAACAACTG-3'), specific to $P$. olseni, were designed by locating unique regions in aligned available Perkinsus species LSU rRNA gene sequences. Digoxigenin-labeled oligos were obtained from Operon Biotechnologies, Inc. (Huntsville, AL). The protocol followed for ISH was that previously published (Stokes \& Burreson, 1995) with the modifications published by Elston et al. (2004). Pronase at a final concentration of $125 \mu \mathrm{g} \mathrm{mL} \mathrm{m}^{-1}$ was used for permeabilization during a 30-min incubation, and a probe concentration of $7 \mathrm{ng} \mu \mathrm{L}^{-1}$ was used for hybridization. The species-specific probes were tested for specificity with numerous Perkinsus sp.-infected reference tissues, including $P$. marinus in C. virginica, $P$. chesapeaki in Mya arenaria Linnaeus, 1758 and P. olseni in Haliotis laevigata Donovan, 1808. Controls for each Perkinsus species-specific probe were tested identically except that they received hybridization buffer lacking probe during the hybridization step. 
TABLE 1.

RFTM ranking and PCR-based Perkinsus genus-specific assay screening results of the challenge study oysters that were notched and inoculated with either SASW or cultured $P$. olseni cells and sampled from the experimental aquaria on days 44,59 and 72.

\begin{tabular}{|c|c|c|c|c|c|c|c|c|c|c|c|c|}
\hline \multirow[b]{2}{*}{ RFTM Ranking } & \multicolumn{2}{|c|}{$\begin{array}{c}\text { Day } 44(n=2) \\
\text { SASW }\end{array}$} & \multicolumn{2}{|c|}{$\begin{array}{c}\text { Day } 44(n=4) \\
\text { P. olseni }\end{array}$} & \multicolumn{2}{|c|}{$\begin{array}{c}\text { Day } 59(n=2) \\
\text { SASW }\end{array}$} & \multicolumn{2}{|c|}{$\begin{array}{c}\text { Day } 59(n=4) \\
\text { P. olseni }\end{array}$} & \multicolumn{2}{|c|}{$\begin{array}{c}\text { Day } 72(n=6) \\
\text { SASW }\end{array}$} & \multicolumn{2}{|c|}{$\begin{array}{c}\text { Day } 72(n=15) \\
\text { P. olseni }\end{array}$} \\
\hline & $\begin{array}{c}\# \\
\text { RFTM }\end{array}$ & $\begin{array}{c}\text { \# PCR } \\
\text { Pos }\end{array}$ & $\begin{array}{c}\# \\
\text { RFTM }\end{array}$ & $\begin{array}{c}\text { \# PCR } \\
\text { Pos }\end{array}$ & $\begin{array}{c}\# \\
\text { RFTM }\end{array}$ & $\begin{array}{c}\text { \# PCR } \\
\text { Pos }\end{array}$ & $\begin{array}{c}\# \\
\text { RFTM }\end{array}$ & $\begin{array}{c}\text { \# PCR } \\
\text { Pos }\end{array}$ & $\begin{array}{c}\# \\
\text { RFTM }\end{array}$ & $\begin{array}{c}\text { \# PCR } \\
\text { Pos }\end{array}$ & $\begin{array}{c}\# \\
\text { RFTM }\end{array}$ & $\begin{array}{c}\text { \# PCR } \\
\text { Pos }\end{array}$ \\
\hline None (N) & 2 & 1 & 2 & 1 & & & 1 & 1 & 3 & 3 & 1 & 1 \\
\hline Rare (R) & & & & & & & & & 3 & 3 & 1 & 1 \\
\hline Very Light (VL) & & & 1 & 1 & & & & & & & $2^{*}$ & 2 \\
\hline Light (L) & & & 1 & 1 & & & 2 & 2 & & & 6 & 6 \\
\hline Light/Moderate (LM) & & & & & & & & & & & 1 & 1 \\
\hline Moderate (M) & & & & & 1 & 1 & 1 & 1 & & & & \\
\hline Moderate/Heavy (MH) & & & & & 1 & 1 & & & & & & \\
\hline Heavy $(\mathrm{H})$ & & & & & & & & & & & 1 & 1 \\
\hline Very Heavy (VH) & & & & & & & & & & & 3 & 3 \\
\hline
\end{tabular}

* Species-specific PCR assays indicated that one of these individuals, as well as one P. olseni-inoculated individual collected on day 21 (data not shown), contained DNA from both P. marinus and P. olseni. Only P. marinus DNA was detected in all other individuals.

\section{RESULTS}

\section{Genus-specific PCR and RFTM Assay Results}

All tissue samples used for DNA extraction yielded high quality genomic DNA as indicated by strong $1,800 \mathrm{bp}$ amplification products that were clearly visible by UV illumination of agarose gels following PCR with the SSU rRNA gene universal primers. Perkinsus genus-specific PCR-based diagnostic screening of an initial baseline subset of 20 C. ariakensis sacrificed on January 24, 2005 showed that all animals were free of Perkinsus DNA. After being held in the laboratory aquaria for 59 days, prior to inoculation, five $C$. ariakensis were sacrificed and genus-specific PCR screening indicated a $100 \%$ prevalence of Perkinsus sp. DNA.

RFTM and Perkinsus genus-specific PCR screening results for the $C$. ariakensis that were inoculated with SASW or $P$. olseni cells are shown in Table 1. RFTM data were not collected during the first day of subsampling (Day 21), however the PCR screening indicated the presence of Perkinsus sp. DNA in both oysters sampled from those inoculated with SASW and in three of the four oysters sampled from the P. olseni injections. There were no Perkinsus cells observed by RFTM assays in the day 44 SASW sample, although Perkinsus sp. DNA was found by the PCR assay in one of the two oysters sampled. Very light-light RFTM rankings were found for two of the four $P$. olseni-inoculated oysters sampled on day 44 and three of the four were positive in the Perkinsus genus-specific PCR assay. On day 59 both of the SASW-inoculated oysters sampled had moderate-moderate/heavy Perkinsus sp. tissue burdens and Perkinsus sp. DNA was found in both by the PCR assay. Three of the four P. olseni-inoculated oysters that were sampled on day 59 had light-moderate infections as indicated by the RFTM assay and Perkinsus DNA was detected in all four of the oysters. On day 72, when the experiment was terminated, six SASW- and 15 P. olseni-treated oysters remained and were sacrificed. Perkinsus DNA was found by the PCR assay in all of the oysters remaining from the two treatment groups (Table 1). Perkinsus sp. cells were not detected, however, by the RFTM assay in three of the SASW-inoculated or in one of the $P$. olseni-inoculated oysters. The other three remaining SASWinoculated oysters had rare RFTM rankings. Rare-light/moderate tissue burdens were found in nine $P$. olseni-inoculated oysters at the end of the experiment and four $P$. olseni-inoculated oysters had heavy-very heavy infections as indicated by the RFTM assay.

RFTM and P. marinus PCR assay results for the 29 untreated C. ariakensis that were still alive and were sacrificed on day 37 of the challenge experiment are shown in Table 2. Eighteen of these oysters were ranked as having rare to light Perkinsus sp. tissue burdens, two were ranked as light/moderate and two as moderatemoderate/heavy tissue burdens. Seven had no observable Perkinsus sp. cells in the RFTM assay, however five of these were positive in the PCR assay. Perkinsus marinus DNA, as indicated by the PCR assay, was found in 23 of these 29 untreated oysters (Table 2), with no DNA detected in three of the oysters with a rare RFTM ranking and in one with a light infection as indicated by the RFTM assay.

\section{Mortality Data}

Mortality was observed in untreated oysters and in those injected with either SASW or P. olseni (Table 3). For the untreated $C$. ariakensis, two died during the 37 day period that they were

TABLE 2.

RFTM ranking and PCR-based $P$. marinus assay screening results of control untreated $C$. ariakensis (unnotched and uninoculated) on day 37 of the challenge study.

\begin{tabular}{lcc}
\hline \hline & \multicolumn{2}{c}{ Day 37 (n=29) } \\
\cline { 2 - 3 } \multicolumn{1}{c}{ RFTM Ranking } & \# Individuals & \# P. marinus PCR+ \\
\hline None (N) & 7 & 5 \\
Rare (R) & 7 & 4 \\
Very Light (VL) & 3 & 3 \\
Light (L) & 8 & 7 \\
Light/Moderate (LM) & 2 & 2 \\
Moderate (M) & 1 & 1 \\
Moderate/Heavy (MH) & 1 & 1 \\
Heavy (H) & & \\
Very Heavy (VH) & & \\
\hline
\end{tabular}

(Note: P. olseni DNA was not detected in any of these oysters.) 
TABLE 3.

Daily observed $C$. ariakensis mortalities during the course of the challenge experiment.

\begin{tabular}{rccc}
\hline \hline Day & Untreated & 25 ppt SASW & Perkinsus olseni \\
\hline 2 & 1 & & \\
11 & 1 & 1 & \\
37 & & & 1 \\
43 & na* & 4 & 1 \\
49 & na & & 1 \\
53 & na & 1 & 4 \\
55 & na & 1 & 1 \\
58 & na & 1 & 2 \\
59 & na & & 1 \\
64 & na & & 6 \\
66 & na & & \\
72 & na & & \\
\hline
\end{tabular}

* na $=$ not applicable because the oysters from the untreated tank were sacrificed on day 37 .

Column headings indicate the sample treatments.

held in the aquaria. For the SASW treatment and the $P$. olseni treatment, cumulative mortality after 72 days was $40.0 \%$ and $46.2 \%$, respectively. Of the 27 dead $C$. ariakensis removed from the untreated tank and the experimental aquaria during the course of the experiment, it was possible to conduct RFTM analysis on 11 oysters and PCR analysis on 22. All tissues taken from dead $C$. ariakensis were PCR positive for Perkinsus sp. DNA. Of these 11 oysters examined by RFTM, 2 had none, or rarely observable Perkinsus sp. cells, 2 had very light or light tissue burdens, 1 had a light/moderate tissue burden and 6 had moderate to heavy tissue burdens of Perkinsus sp. cells.

\section{Species-specific PCR Screening for Perkinsus marinus and}

\section{Perkinsus olseni}

DNAs from all oysters shown to be PCR positive with the Perkinsus genus-specific assay were analyzed using both $P$. mari$n u$-specific and $P$. olseni-specific primers. Because the $P$. olseni primers were new for this study, specificity was tested against $P$. marinus and $P$. chesapeaki DNAs. The $P$. olseni primers did not amplify DNA from these other Perkinsus species. Sequencing of amplification products further confirmed the specificity as sequences of amplification products from all positive $P$. olsenispecific reactions matched those of GenBank deposited P. olseni ( $P$. atlanticus) sequences. The five $C$. ariakensis taken as a baseline sample immediately prior to the start of the study, and all untreated oysters had only $P$. marinus DNA. In addition, all but two of the $C$. ariakensis that were SASW- or $P$. olseni-inoculated and that were Perkinsus sp. positive with the genus-specific primers, were positive for only $P$. marinus DNA. Two oysters that were inoculated with $P$. olseni at the start of the challenge and were sampled on days 21 and 72 were positive for both $P$. marinus and for $P$. olseni DNA. Tissue from all dead oysters collected from either the experimental or untreated aquaria were found to be PCR-positive for P. marinus only.

\section{RFLP Results}

The $P$. olseni and $P$. marinus positive control DNA isolated from cultured cells, and plasmid-purified Perkinsus chesapeaki
ITS region DNA, were amplified in the Perkinsus genus-specific assay and were digested with $M b o$ I restriction endonuclease. Results confirmed that $P$. marinus ITS region DNA has a unique digestion profile when digested with $M b o$ I and the observed fragment sizes of approximately $17 \mathrm{bp}, 226 \mathrm{bp}$ and $264 \mathrm{bp}$ were consistent with the fragment sizes expected for P. marinus.

\section{Histology}

Ten animals shown by PCR to have Perkinsus sp. DNA, and whose tissues showed light to very heavy RFTM rankings were chosen for further histological examination. A tissue section from one animal with a very heavy RFTM ranking that had died during the experiment showed gross lesions (Fig. 1A) and observable parasite cells when stained with Harris-hemotoxylin and eosin (Fig. 1B). Parasite cells were numerous and observed systemically
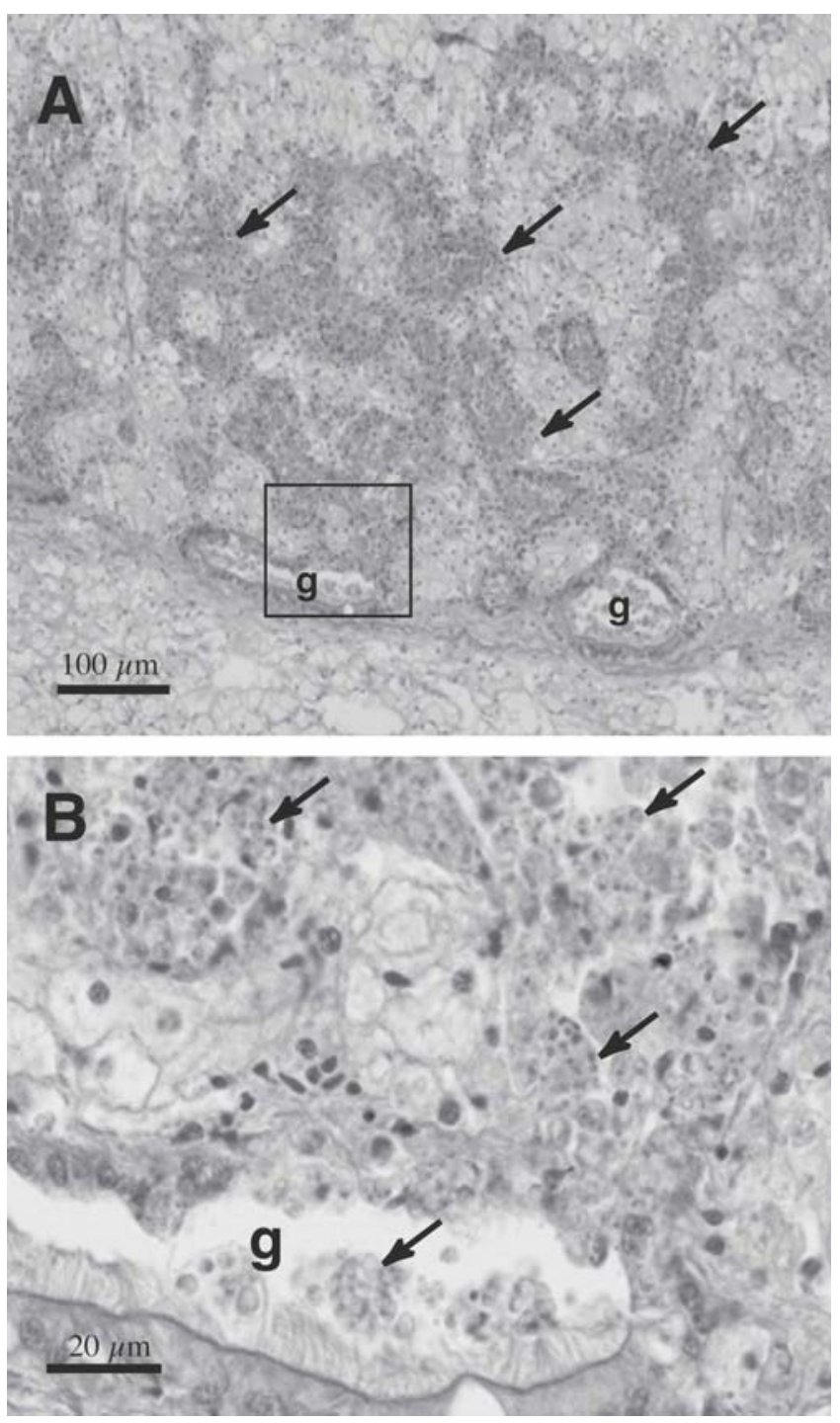

Figure 1. H\&E-stained histological section of Perkinsus marinus lesions in the gonad of Crassostrea ariakensis. (A) Low power photomicrograph showing the extent of the lesions (arrows) in the vicinity of the gonoduct (g). Square represents the area shown in B. (B) Higher magnification in the vicinity of a gonoduct (g) showing $P$. marinus cells (arrows) in the lesions. 
throughout the visceral mass. Obvious lesions caused by Perkinsus sp. infection were not observed by histology in tissue sections taken from animals with light or moderate Perkinsus sp. tissue burdens as determined by the RFTM assays.

\section{ISH Assay Results}

In-situ hybridization probes designed to target the LSU rRNA genes of $P$. marinus or $P$. olseni exhibited specificity for the targeted Perkinsus species. In the specificity tests, the $P$. marinus probe hybridized only to the Perkinsus cells in the sample of $P$. marinus in $C$. virginica and the $P$. olseni probe hybridized to Perkinsus sp. cells in the control sample of P. olseni in Haliotis laevigata. The probes did not cross-react with nontargeted Perkinsus species or host tissues in other control samples. Figure 2A to D shows four consecutive sections from the heavily infected oyster shown in Figure 1. Figure $2 \mathrm{~A}$ is an H\&E-stained section. Figure 2B shows positive in-situ hybridization with the PmarDIGLSU181 probe to Perkinsus sp. cells indicating that the lesions were caused by $P$. marinus. The $P$. marinus-specific probe bound to cells throughout the digestive epithelium, gonads and gonoducts. In situ hybridization reactions conducted without probe (Fig. 2C), or with the PolsDIGLSU-464 probe (Fig. 2D), produced no signal in host tissues of this oyster. The PolsDIGLSU-464 probe was also tested against two individuals that were inoculated with $P$. olseni and found to harbor both $P$. marinus and $P$. olseni DNA by the PCR assays. The $P$. marinus probe hybridized to Perkinsus sp. cells in the dually infected oysters, however, no binding of the $P$. olseni probe was observed, suggesting that infections by $P$. olseni were extremely light, or that only $P$. olseni DNA was present and not viable cells.
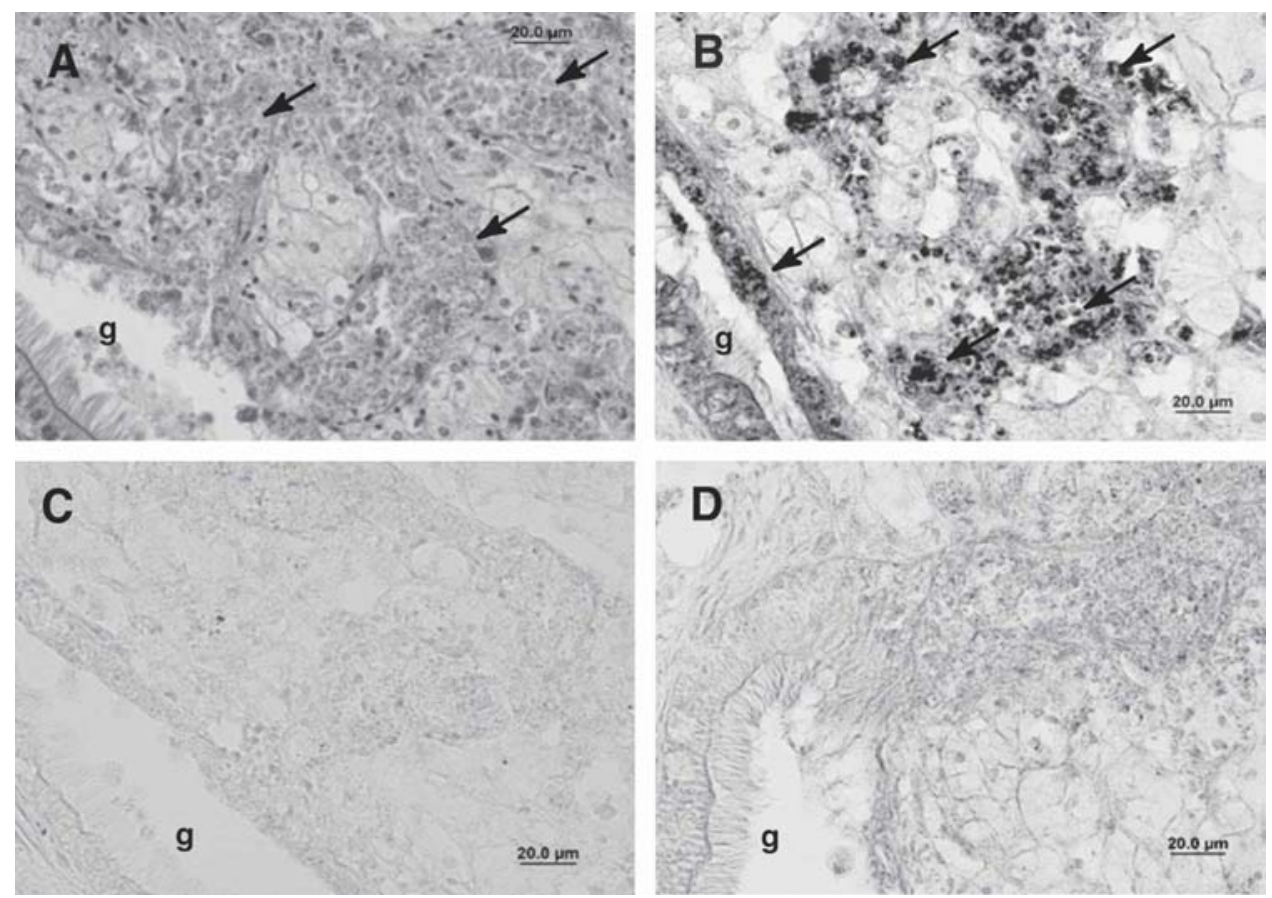

Figure 2. Perkinsus marinus in Crassostrea ariakensis. (A) H\&E-stained histological section in the vicinity of a gonoduct (g) showing Perkinsus marinus lesions (arrows). (B) In situ hybridization with the $P$. marinus-specific probe, Pmar181LSUDIG, illustrating strong binding to the Perkinsus sp. cells (arrows). (C) No probe negative control showing no binding to the $C$. ariakensis tissue. (D) In situ hybridization with the $P$. olseni-specific probe, Pols464LSUDIG, illustrating no binding to the Perkinsus sp. cells.

\section{DISCUSSION}

Initial screening using a PCR-based diagnostic method on a sample of the triploid $C$. ariakensis oysters that were obtained for the challenge study suggested that they did not harbor $P$. marinus. A small sample $(n=5)$ of these oysters screened 59 days later, however, had $100 \%$ P. marinus DNA prevalence as indicated by the $P$. marinus- specific PCR assay. We suggest that the $C$. ariakensis oysters either acquired a small number of $P$. marinus cells that were not numerous enough to be detected by our initial PCR assay of gill/mantle tissue, while in the VIMS hatchery before collection for this experiment, or while being held in unfiltered York River water for 4 days prior to being brought into the aquaria where they were subsequently held only in filtered York River water. The $P$. marinus proliferated to PCR detectable levels after 59 days in aquaria with disease developing and mortality subsequently occurring in not only those oyster groups that had been subjected to notching and inoculation with either SASW or $P$. olseni for the challenge study, but also in the control group of unnotched and untreated oysters that were simply held for an additional 37 days during the challenge experiment.

RFTM and PCR assay results for the C. ariakensis initially inoculated with either $25 \mathrm{ppt}$ SASW or cultured $P$. olseni cells for the challenge study revealed a progression of $P$. marinus infection in the oyster tissues. Sampling and subsequent PCR-based screening of both the $25 \mathrm{SASW}$ and $P$. olseni-inoculated oysters on Days 21 and 44 indicated that $P$. marinus DNA was found in $83.3 \%$ and $66.7 \%$ of the oysters, respectively. We believe that the apparent decrease in $P$. marinus prevalence on day 44 reflects sampling error related to the small sample sizes $(n=6)$ assayed to determine PCR-based Perkinsus sp. prevalence at each time 
point. Although P. olseni DNA was found in two of the P. olseniinoculated oysters (one each on days 21 and 72), there was an increase in the observed PCR prevalence of $P$. marinus DNA to $100 \%$ in samples of all treated oysters collected on days 59 and 72. Likewise, as determined by RFTM assays, the tissue burdens for the two positive individuals were light in the $P$. olseni-treated oysters collected on day 44 of the experiment. However, among samples of these same oyster groups that were collected on days 59 and 72 , not only light infections, but also moderate to very heavy tissue burdens were observed. Interestingly, disease progression in those $C$. ariakensis not notched or inoculated, mimicked that seen in the manipulated experimental oysters based on the RFTM-based tissue burdens. By day 37 when the control oysters were sacrificed, the observed Perkinsus sp. tissue burdens ranged from light to moderate/heavy.

During the course of the experiment, there were many instances where dead oysters were discovered in the various treatment groups, with little or no tissue available for either PCR or RFTM analysis. It is important to note, however, that of the 1 dead oysters with available tissue, more than half $(55 \%)$ had moderate to heavy tissue burdens.

Prevalence and intensity of $P$. marinus infections in $C$. virginica oysters are closely linked to temperature and salinity, and the rate of infection in the natural environment is believed to be proportional to the number of waterborne infective cells (Andrews $\&$ Hewatt 1957, Chu et al. 1994). Warm water temperatures, $20^{\circ} \mathrm{C}$ to $25^{\circ} \mathrm{C}$, and high salinity $>15 \mathrm{ppt}$, have been shown to correlate with times of maximal proliferation of parasite cells, as well as highest incidences of infection in oysters (Andrews \& Hewatt 1957, Chu et al. 1994). Mortality of infected oyster hosts depends on the level of infection, with an apparent dose of between 10 and 100 cells adequate to establish infection (Chu 1996). Because of the effects of salinity and temperature on the parasite, the infections caused by $P$. marinus are seasonal in the Chesapeake Bay, with maximum parasite prevalence recorded in late summer and minimum prevalence observed during the winter months (Burreson \& Ragone Calvo 1996). York River water conditions during the time that the oysters were in the holding tank were approximately $9^{\circ} \mathrm{C}$ and $16 \mathrm{ppt}$ salinity. Environmental conditions of the York River were not likely favorable for $P$. marinus proliferation at the start of these experiments; however, it has been shown that parasite cells can remain viable in over wintering conditions of temperatures as low as $4^{\circ} \mathrm{C}$ and a salinity of 4 ppt (Chu \& Greene 1989, Ragone Calvo \& Burreson 1994, Chu 1996). Therefore, we cannot discount the possible presence of parasite cells in the York River water during the holding period, when the oysters were in unfiltered water. The experimental conditions under which the oysters were held, $20^{\circ} \mathrm{C}$ and $25 \mathrm{ppt}$ salinity, would have favored the proliferation of $P$. marinus cells present in the oysters, accounting for the increase in infection prevalence observed after the baseline sampling.

Cumulative mortalities were highest in those treatments where oysters were subjected to the extra stress of notching and injection, and the highest Perkinsus sp. tissue burdens were seen in dead $C$. ariakensis. We may have observed higher cumulative mortalities in the untreated control oysters, as well, had they been held for a longer time period. In $C$. virginica, digestive gland epithelia and the stomach are often heavily colonized with $P$. marinus and damaged. As parasite proliferation increases to lethal levels, massive tissue sloughing occurs, which eventually contributes to the death of the animals (Mackin, 1951). In this study, tissue sections from a moribund $C$. ariakensis with a very heavy RFTM ranking showed dense, systemic $P$. marinus infection and the ISH assays confirmed that all of the observable Perkinsus sp. cells were P. marinus. Collectively, the results presented here strongly suggest that $P$. marinus was an important contributing factor to the death of these oysters.

Because $P$. olseni was found during a recent survey of $C$. ariakensis populations in Asia (Moss \& Reece 2005), this study was initiated to examine the pathogenicity of $P$. olseni to $C$. ariakensis. At the termination of this experiment, however, PCR based diagnostics suggested that a relatively low number of the $P$. olseni-inoculated $C$. ariakensis $(n=2)$ harbored both $P$. marinus and $P$. olseni DNA. This result may indicate that $C$. ariakensis are not readily susceptible to $P$. olseni, or that virulence attenuation of the parasite may have occurred during the culturing period prior to the use of the parasite as inoculum. Virulence attenuation with in-vitro cultured P. marinus cells has been documented (Ford et al. 2002). Recent studies, however, have demonstrated that cultured cell virulence is enhanced by supplementing media with host oyster homogenate (MacIntyre et al. 2003, Earnhart et al. 2004) and therefore, we plan to do homogenate supplementation of media for Perkinsus sp. isolates used in future challenge studies.

Although little data on $P$. olseni pathogenicity was obtained during this experiment, it provided valuable information regarding the potential for advanced $P$. marinus infections to occur in $C$. ariakensis. Prior field studies conducted in Chesapeake Bay have indicated that although $C$. ariakensis is capable of acquiring $P$. marinus infections (Calvo et al. 2001), there was no evidence that C. ariakensis was susceptible to the advanced parasite infections known to occur in $C$. virginica. We contend that the experimental environmental conditions, under which the oysters were held for a total of 5 months, combined with the stress of the unnatural aquaria environment and experimental manipulation, may have promoted the development of the intense $P$. marinus infections in $C$. ariakensis that were observed here. This study provides valuable information on potentially problematic disease issues including parasite proliferation that can arise if $P$. marinus-infected $C$. ariakensis encounter stress challenges in the wild or aquaculture environment, or if they are held in hatcheries or laboratories under stressful conditions.

\section{ACKNOWLEDGMENTS}

The authors thank Dr. S.K. Allen, Jr. of the Aquaculture and Genetics Breeding Center at VIMS for providing Crassostrea ariakensis oysters; Georgeta Constantin and Alanna MacIntyre for technical assistance in experimental set-up and Dr. Hamish Small for providing editorial assistance. This research was supported by a NOAA/Sea Grant award \# R/A-36 and a NOAA/NMFS Nonnative Oyster Research Program award \#NA04NMF4570431. VIMS contribution number 2718.

\section{LITERATURE CITED}

Andrews, J. D. \& W. G. Hewatt. 1957. Oyster mortality studies in Virginia. II. The fungus disease caused by Dermocystidium marinum in oysters of the Chesapeake Bay. Ecol. Monogr. 27:1-26.
Audemard, C., K. S. Reece \& E. M. Burreson. 2004. Real-time PCR for the detection and quantification of the protistan parasite Perkinsus marinus in environmental waters. Appl. Environ. Micro. 70:6611-6618. 
Burreson, E. M. \& L. M. Ragone Calvo. 1996. Epizootiology of Perkinsus marinus disease of oysters in Chesapeake Bay, with emphasis on data since 1985. J. Shellfish Res. 15:17-34.

Calvo, G. W., M. W. Luckenbach \& E. M. Burreson. 1999. A comparative field study of Crassostrea gigas (Thunberg, 1973) and Crassostrea virginica (Gmelin, 1791) in relation to salinity in Virginia. J. Shellfish Res. 18(2):459-464.

Calvo, G. W., M. W. Luckenbach, S. K. Allen, Jr. \& E. M. Burreson. 2001 A comparative field study of Crassostrea ariakensis (Fujita 1913) and Crassostrea virginica (Gmelin) in relation to salinity in Virginia. $J$. Shellfish Res. 20:221-229.

Casas, S. M., A. Villalba \& K. S. Reece. 2002. Study of perkinsosis in the carpet shell clam Tapes decussates in Galacia (NW Spain). Identification of the aetiological agent and in vitro modulation of zoosporulation by temperature and salinity. Dis. Aquat. Org. 50:51-65.

Chu, F.-L. E. 1996. Laboratory investigations of susceptibility, infectivity, and transmission of Perkinsus marinus in oysters. J. Shellfish Res. 15(1):57-66.

Chu, F.-L. E. \& K. H. Green. 1989. Effect of temperature and salinity on in vitro culture of the oyster pathogen, Perkinsus marinus, (Apicomplexa: Perkinsea). J. Invertebr. Pathol. 53:260-268.

Chu, F.-L. E., A. K. Volety \& G. Constantin. 1994. Synergistic effects of temperature and salinity on the response of oysters (Crassostrea virginica) and Pacific (Crassostrea gigas) oysters: temperature and salinity effects. J. Shellfish Res. 12(1):21-27.

Earnhart, C. G., M. A. Vogelbein, G. B. Brown, K. S. Reece \& S. L. Kaattari. 2004. Supplementation of Perkinsus marinus cultures with host plasma or tissue homogenate enhances their infectivity. Appl. Environ. Microbiol. 70(1):421-431.

Elston, R. A., C. F. Dungan, T. R. Meyers \& K. S. Reece. 2004. Perkinsus sp. infection risk for Manila clams, Venerupis philippinarum (A. Adams and Reeve, 1850) on the Pacific coast of North and Central America. J. Shellfish Res. 23(1):101-105.
Ford, S. E., M. M. Chintala \& D. Bushek. 2002. Comparison of in-vitrocultured and wild-type Perkinsus marinus. I. Pathogen virulence. Dis. Aquat. Org. 51(4):187-201.

MacIntyre, E. A., C. G. Earnhart \& S. L. Kaattari. 2003. Host oyster tissue extracts modulate in vitro protease expression and cellular differentiation in the protozoan parasite, Perkinsus marinus. Parasitology 126: 293-302.

Mackin, J. G. 1951. Histopathology of infection of Crassostrea virginica (Gmelin) by Dermocystidium marinum Mackin. Owen and Collier. Bull. Mar. Sci. Gulf and Caribbean 1:72-87.

Medlin, L., H. J. Elwood, S. Stickel \& M. L. Sogin. 1988. The characterization of enzymatically amplified eukaryotic16S-like rRNA-coding proteins. Gene 71:491-499.

Moss, J. A. \& K. S. Reece. 2005. Pathogens of the Asian oyster, Crassostrea ariakensis, in its native range: current findings and work in progress. J. Shellfish Res. 24(2):668.

Ragone Calvo, L. M. \& E. M. Burreson. 1994. Characterization of overwintering infections of Perkinsus marinus (Apicomplexa) in Chesapeake Bay oysters. J. Shellfish Res. 13:123-130.

Ray, S. M. 1952. A culture method for the diagnosis of infections with Dermocystidium marinum Mackin, Owen and Collier in oysters. Science 116:360-361.

Ray, S. M. 1954. Biological studies of Dermocystidium marinum, a fungus parasite of oysters. Rice Institute Pamphlet. 114 pp.

Shaw, B. L. \& H. I. Battle. 1957. The gross microscopic anatomy of the digestive tract of the oyster Crassostrea virginica (Gmelin). Can. J. Zool. 35:325-357.

Sindermann, C. J. 1990. Principal diseases of marine fish and shellfish. Vol. 2. San Diego, CA: Academic Press, Inc. 516 pp.

Stokes, N. A. \& E. M. Burreson. 1995. A sensitive and specific DNA probe for the oyster pathogen Haplosporidium nelsoni. J. Eukaryot. Microbiol. 42:350-357. 